\title{
Studies on Success of Different Age Rootstocks of Softwood Grafting in Jamun (Syzygium cuminii Skeels)
}

\author{
Chongtham Allaylay Devi ${ }^{*}$, G.S.K. Swamy ${ }^{1}$, Brij Bihari Pandey ${ }^{3}$, Nagesh Naik ${ }^{2}$, \\ P.M. Sampath ${ }^{2}$, G.J. Suresha ${ }^{4}$ and Mukesh L. Chavan ${ }^{5}$
}

${ }^{1}$ Department of Fruit Science, ${ }^{3}$ Department of crop physiology, College of Agriculture, IGKV, Raipur, Chhattisgarh-492012, India

${ }^{2}$ Department of Fruit Science, ${ }^{4}$ Department of Post-Harvest Technology, ${ }^{5}$ Department of Crop Physiology, K.R.C. College of Horticulture, Arabhavi - 591 218, Belgaum Karnataka, India

*Corresponding author

\section{A B S T R A C T}

\section{Keywords}

Softwood grafting, Graft success, Graft survival

\section{Article Info}

Accepted: 26 January 2018 Available Online: 10 February 2018
An investigation on "Success of softwood grafting in jamun" was carried out in department of Fruit Science, Kittur Rani Channamma College of horticulture, Arabhavi during year 2015-16. Seven treatments comprised of different age of rootstocks viz., $\mathrm{T}_{1}(6$ month), $\mathrm{T}_{2}$ (5 and half month), $\mathrm{T}_{3}\left(5\right.$ month), $\mathrm{T}_{4}$ (4 and half month), $\mathrm{T}_{5}$ (4 month), $\mathrm{T}_{6}(3$ and half month) and $\mathrm{T}_{7}(3$ month) were used for softwood grafting. The influence of age of rootstocks on the graft success and graft survivability at 60 and 90 days after grafting (DAG) did not show significant difference among the treatments. At 30, 60 and 90 DAG, significantly differences were observed for graft girth and number of sprouts. At 30 and 60 DAG, significant higher number of leaves per graft was recorded. Thus, the findings of the present investigation may be helpful in improvement programme, enhancing for large scale multiplication.

\section{Introduction}

Jamun (Syzygium cuminii Skeels.) is an evergreen multipurpose tree. It is an important minor fruit belonging to the family Myrtaceae consisting of over 75 species and is a native of India. It is also known as Black Plum, Java Plum, Indian blackberry, Jambolan, etc. It is tall and evergreen tree distributed throughout India for its edible fruits. It is highly adapted to diverse environmental conditions and grows successfully in all tropical and sub-tropical parts. It is hardy crop and suitable for marginal and wasteland. The fruit being highly nutritive and possess great medicinal value as such gained importance. They are good source of iron, minerals, sugars and proteins. Sucrose and fructose are the principle sugar in the ripe fruit. Fruits are also used for making squashes, jellies, jam, wine, pickles and vinegar. The fruits are tasty and pleasantly flavored and are very much liked by the masses and mostly used as a dessert purpose (Ochse et al., 1961). Jamun is highly valued for its fruits, seeds and leaves and are recommended to control diabetes, dysentery, 
diarrhoea, edema, ringworm, fever, etc. Apart from antidiabetic preparations, the seeds are also known to be very good concentrate feed to the cattle as they are rich in protein, carbohydrates and calcium (Hayes, 1970). Jamun being relatively minor fruit crop, organized culture in the form orchard is rarely noticed under the Indian conditions. Looking at the importance of the fruits and high price value, the demand for its planting material is also increasing. Due to lack of any suitable or recommended variety, the farmers have been planting trees of either seedling origin or grafted plants of unknown yield potential and fruit quality. In nature, lot of variation with respect to fruit shape and size, TSS, acidity and earliness in bearing of this crop is evident. Advantages of these variations can be taken to evolve selections of superior quality. Survey and selection are the best procedures to evolve suitable genotypes for a particular area of its natural existence. To increase the productivity, there should be availability of good planting material along with proper management practices. The crop can be propagated sexually, through seeds and asexually by the use of grafting. This experiment was conducted to find out the optimum age of the rootstock to get maximum success in softwood grafting.

\section{Materials and Methods}

The present investigation was carried out during the year 2015-2016 at K.R.C. College of Horticulture, Arabhavi in Belgaum district of Karnataka. The experiment was laid in Completely randomized design along with seven treatments comprised of different age of rootstocks viz., $\mathrm{T}_{1}$ (6 month), $\mathrm{T}_{2}$ (5 and half month), $\mathrm{T}_{3}$ (5 month), $\mathrm{T}_{4}$ (4 and half month), $\mathrm{T}_{5}\left(4\right.$ month), $\mathrm{T}_{6}$ (3 and half month) and $\mathrm{T}_{7}$ (3 month)with three replications. Observations were recorded in respect of 30,60 and 90 days after grafting respectively. The data for per cent graft success and per cent graft survivability graft height $(\mathrm{cm})$, Graft girth (mm), Number of leaves and Number of sprouts were recorded. Graft height was measured with scale from the base of the graft to the tip of the scion shoot at monthly interval and was expressed in centimetres. Graft girth was measured from the base of grafted portion with Vernier callipers. The number of leaves emerged on from the scion were counted and recorded at monthly intervals. The number of sprouts arising from the grafted plant, above the graft union was counted at monthly intervals after grafting. Those grafts in which the scion had sprouted and remained alive without shrivelling at the time of observation (after three months of grafting) were noted and percentages of graft success were worked out.Survival of the graft was recorded three months after grafting by the following formula and expressed in percentage.

Number of successful grafts

Graft success =

$$
\text { Total number grafts }
$$

Number of grafts remained alive Graft survival = -------------------------- X 100

Total number of successful grafts

\section{Results and Discussion}

\section{Graft take}

\section{Per cent graft success (at 60 days after grafting)}

The data on per cent graft success as influenced by different age rootstocks are presented in Table 1 and Plates 1, 2 and 3. Perusal of data indicated that the influence of different age of rootstocks on graft take after two months of grafting was no significant. The per cent graft success varied from 65.01 per cent to 74.82 per cent among the different age of rootstocks. 
Maximum per cent graft success was recorded in $\mathrm{T}_{1}(74.82 \%)$ which was on par with $\mathrm{T}_{4}$ $(72.43 \%)$. Minimum graft success percentage was recorded in $\mathrm{T}_{2}(65.01 \%), \mathrm{T}_{7}(65.36 \%)$ and $\mathrm{T}_{6}(65.45 \%)$ which was $\mathrm{T}_{5}$ and $\mathrm{T}_{3}(68.91 \%$ and $69.05 \%$, respectively).

\section{Per cent graft survivability (at 90 days after grafting)}

The data on per cent graft survivability as influenced by different age rootstocks are presented in Table 1. The survivability of grafts at three months after grafting did not show significant difference among the different age of rootstocks grafting. The mean graft survivability ranged from 49.76 per cent to 64.87 per cent among the different age of rootstocks grafting. At $30 \mathrm{DAG}$, the number of sprouts in grafts showed significant difference among the treatments. Maximum number of sprouts was produced in $\mathrm{T}_{7}$ grafted plants (2.86) which were on par with $\mathrm{T}_{2}$ grafted plants (2.63).

The minimum number of sprouts was recorded in $\mathrm{T}_{6}$ grafted plants (1.77). At 60 DAG, maximum number of sprouts was produced in $\mathrm{T}_{7}$ grafted plants (2.89) which was on par with $\mathrm{T}_{2}$ grafted plants (2.82). Minimum number of sprouts was recorded in $\mathrm{T}_{6}$ grafted plants (2.02) followed by $\mathrm{T}_{4}$ grafted plants (2.06).At 90 DAG, maximum number of sprouts was produced in $\mathrm{T}_{2}$ grafted plants (3.02) which was on par with $\mathrm{T}_{7}$ grafted plants (2.95). The lowest number of sprouts was recorded in $\mathrm{T}_{4}$ grafted plants (2.10) followed by $\mathrm{T}_{6}$ grafted plants (2.27).

\section{Number of leaves}

The data on number of leaves per graft as influenced by different age rootstocks are presented in Table 2. At $30 \mathrm{DAG}$, the number of leaves in grafts showed significant difference among the treatments. Maximum number of leaves was produced in $\mathrm{T}_{2}$ grafted plants (13.10) which was on par with $T_{7}$ grafted plants (12.45). The minimum number of leaves was recorded in $\mathrm{T}_{6}$ grafted plants (7.27). At 60 DAG, highest number of leaves was produced in $\mathrm{T}_{2}$ grafted plants (13.70) which was on par with $\mathrm{T}_{7}$ grafted plants (13.03). Lowest number of leaves was recorded in $\mathrm{T}_{6}$ grafted plants (9.19) followed by $\mathrm{T}_{3}$ and $\mathrm{T}_{4}$ grafted plants (9.30 and 9.53 , respectively). At $90 \mathrm{DAG}$, there was no significant difference for number of leaves per graft. Comparatively maximum number of leaves was produced in $\mathrm{T}_{2}$ grafted plants (14.49). There was not much variation for number of leaves among the seven treatments.

The study revealed that success of grafting significantly differed among rootstocks of different age. Results revealed that there were no significant differences among the different age of rootstocks.

Maximum graft success was reported in case of six months old rootstock sand minimum was noticed with five and half month old rootstock which was on par with three and three and half month old rootstocks (Table 1). Satishkumar (2001) in tamarind reported highest graft success in eight and seven months old rootstocks under Dharwad conditions. He attributed that the effect may be due to the physiological maturity of rootstock which plays an important role in the success and growth of grafts as reported by many other workers in different crops. Jayaramagowda and Melanta (1989) opined that the young rootstocks give more success in softwood grafting than older ones.

Similar results were also obtained by several workers in different crops of cashew, cashew and mango respectively. Muniswami (1979) and Reddy and Melanta (1988). Dambal (1999) working on sapota at UAS, Dharwad 
reported the highest graft success with eight months old rootstocks followed by nine months old rootstocks. Further, It was evident from the present investigation that the rootstocks with appropriate vigour and physiological maturity recorded maximum survival per cent, which was noticed in rootstocks like six, five and three months old than the four and half months old rootstocks (Table 2). Hartmann and Kester (1979) opined that, the age of rootstock has relationship with regenerating ability of a plant part which is found to be higher in younger rootstocks and this is because of higher activity of meristematic cells resulting in faster formation of callus and quick healing of graft union.

Plate.1 General view of grafted plant

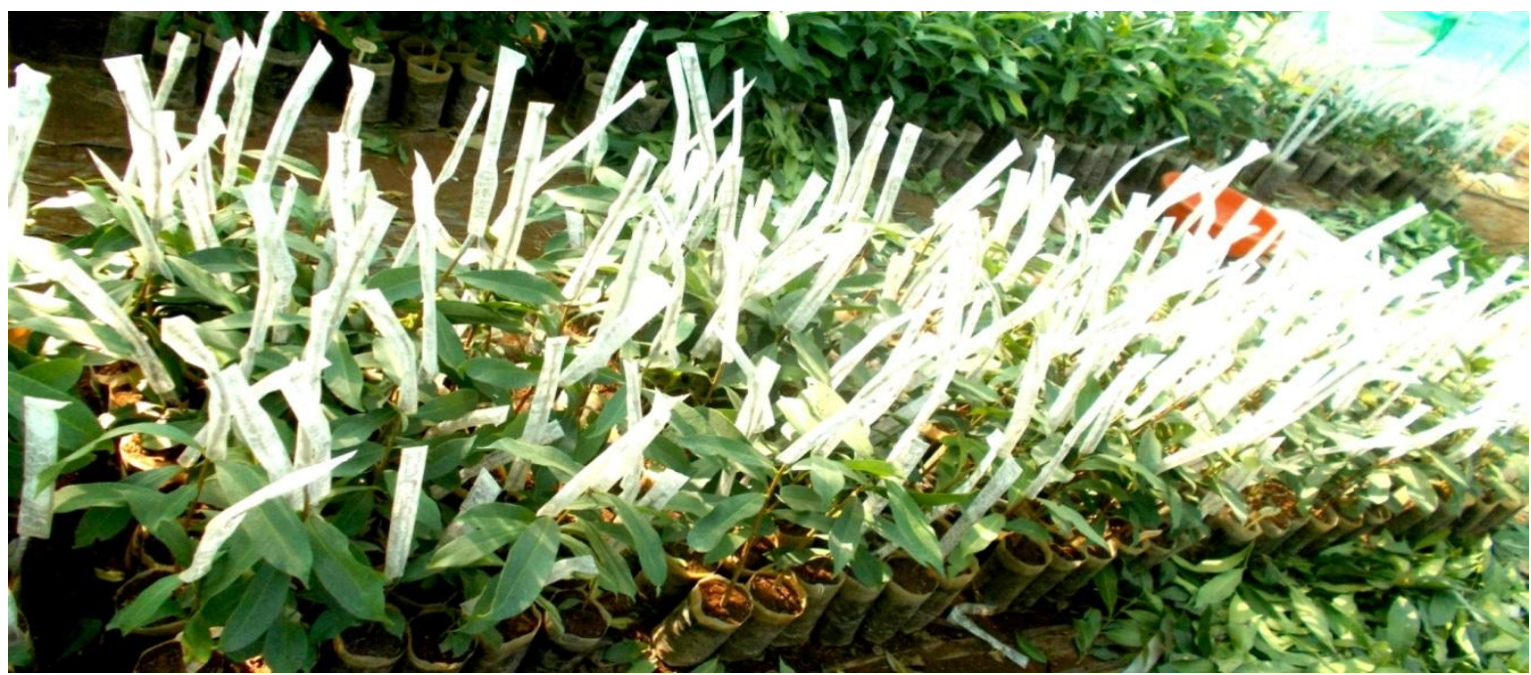

Plate.2 General view of successful grafted plant

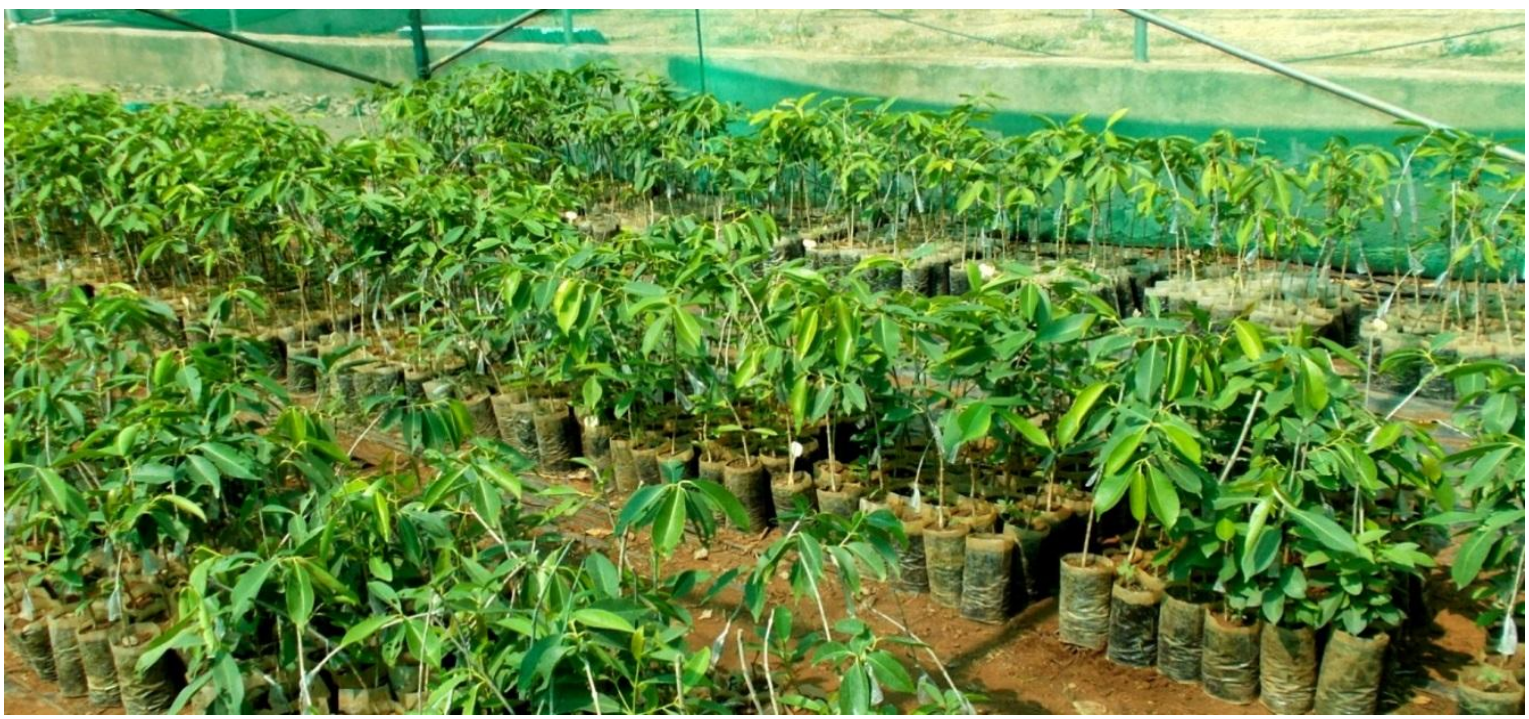


Plate.3 Successful grafts with different treatment age of rootstocks

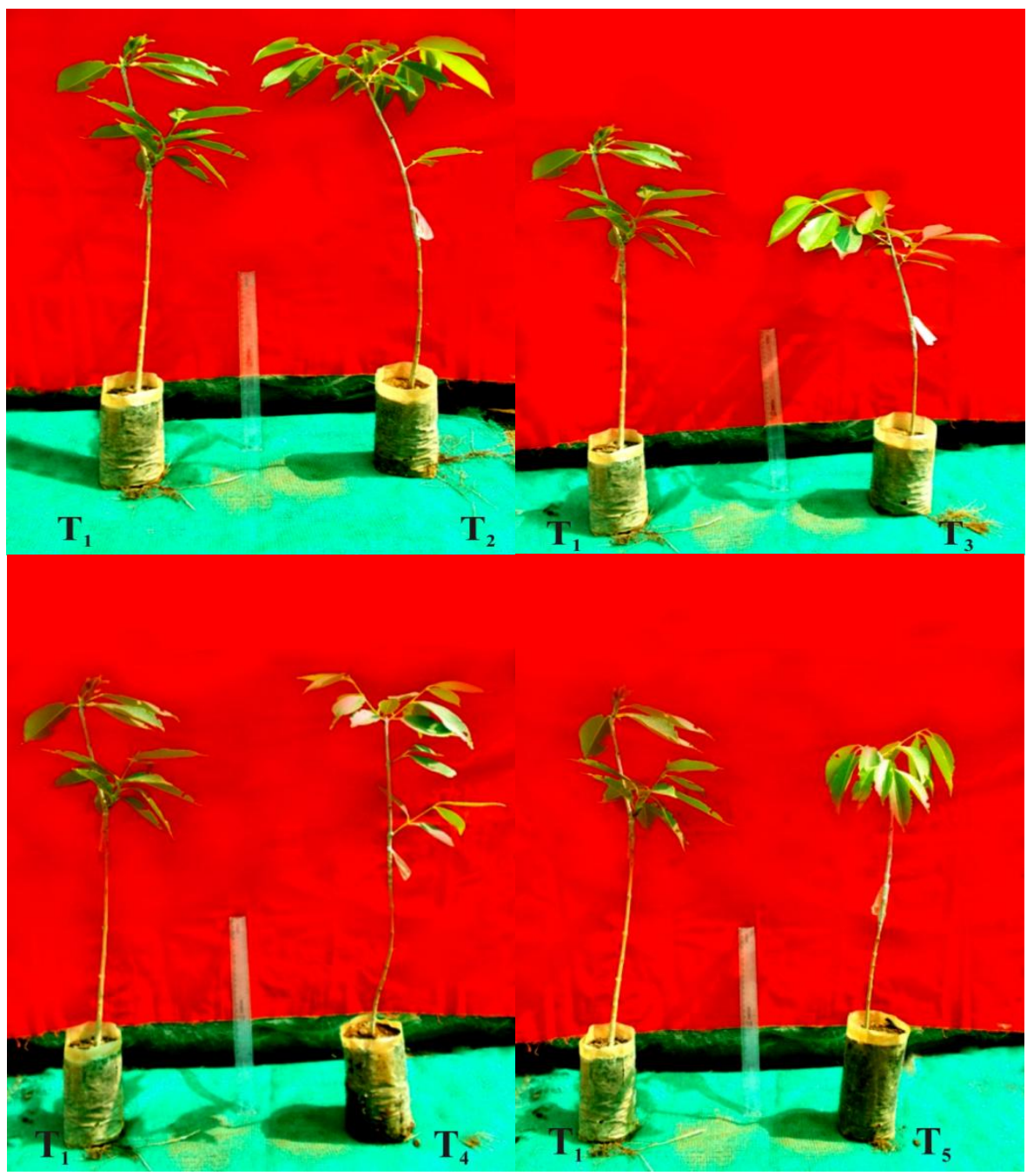


Int.J.Curr.Microbiol.App.Sci (2018) 7(2): 3158-3165

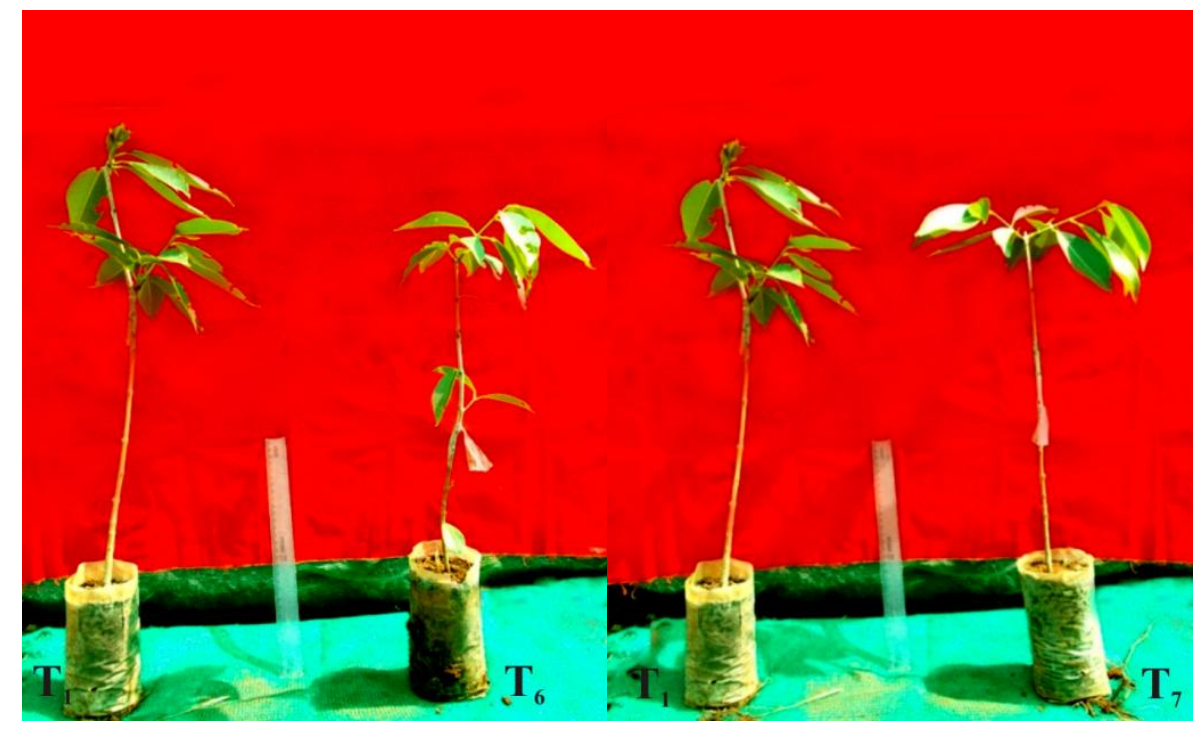


Table.2 Effect of different age of rootstocks on growth characters of softwood grafts

\begin{tabular}{|c|c|c|c|c|c|c|c|c|c|c|c|c|}
\hline \multirow[t]{2}{*}{ Treatment } & \multicolumn{3}{|c|}{ Graft height (cm) } & \multicolumn{3}{|c|}{ Graft girth (mm) } & \multicolumn{3}{|c|}{ Number of sprouts } & \multicolumn{3}{|c|}{ Number of leaves } \\
\hline & 30 DAG & $\begin{array}{c}60 \\
\text { DAG }\end{array}$ & $\begin{array}{c}90 \\
\text { DAG }\end{array}$ & 30 DAG & $\begin{array}{c}60 \\
\text { DAG }\end{array}$ & $\begin{array}{c}90 \\
\text { DAG }\end{array}$ & 30 DAG & 60 DAG & $\begin{array}{c}90 \\
\text { DAG }\end{array}$ & 30 DAG & 60 DAG & $\begin{array}{c}90 \\
\text { DAG }\end{array}$ \\
\hline $\mathbf{T}_{1}$ & 23.33 & 25.20 & 27.07 & 5.35 & 6.01 & 6.67 & 2.22 & 2.44 & 2.66 & 9.74 & 10.62 & 11.91 \\
\hline $\mathbf{T}_{2}$ & 22.82 & 23.96 & 25.10 & 5.62 & 5.94 & 6.27 & 2.63 & 2.82 & 3.02 & 13.10 & 13.70 & 14.49 \\
\hline $\mathbf{T}_{3}$ & 22.33 & 24.86 & 27.27 & 4.88 & 5.02 & 5.17 & 2.05 & 2.63 & 2.72 & 8.38 & 9.30 & 10.22 \\
\hline $\mathbf{T}_{4}$ & 19.61 & 23.37 & 27.13 & 5.04 & 5.28 & 5.53 & 2.01 & 2.06 & 2.10 & 8.68 & 9.53 & 11.72 \\
\hline$T_{5}$ & 23.88 & 25.12 & 26.36 & 5.20 & 5.32 & 5.41 & 2.55 & 2.55 & 2.55 & 10.72 & 12.18 & 12.66 \\
\hline$T_{6}$ & 21.41 & 24.90 & 27.14 & 4.77 & 5.09 & 5.42 & 1.77 & 2.02 & 2.27 & 7.27 & 9.19 & 11.44 \\
\hline $\mathrm{T}_{7}$ & 25.39 & 26.02 & 26.61 & 5.04 & 5.12 & 5.21 & 2.86 & 2.89 & 2.95 & 12.45 & 13.03 & 13.64 \\
\hline S.Em \pm & 1.127 & 0.365 & 0.660 & 0.119 & 0.086 & 0.177 & 0.118 & 0.183 & 0.176 & 0.878 & 0.891 & 0.987 \\
\hline CD at $5 \%$ & NS & NS & NS & 0.359 & 0.275 & 0.538 & 0.388 & 0.551 & 0.541 & 2.655 & 2.700 & NS \\
\hline $\begin{array}{l}\text { DAG- Day } \\
\mathrm{T}_{1} \text { : Six mo } \\
\mathrm{T}_{5} \text { : Four } \mathrm{m}\end{array}$ & & $\begin{array}{l}\text { NS- Non s } \\
\mathrm{T}_{2}: \text { Five a } \\
\mathrm{T}_{6}: \text { Three }\end{array}$ & $\begin{array}{l}\text { ificant } \\
\text { half mon } \\
\text { d half mo }\end{array}$ & & $\begin{array}{l}\text { Five mo } \\
\text { Three }\end{array}$ & & $T$ & alf month & & & & \\
\hline
\end{tabular}


Table.1 Effect on different age of rootstocks on softwood grafting success and graft survivability

\begin{tabular}{|l|c|c|}
\hline \multicolumn{1}{|c|}{ Treatment } & $\begin{array}{c}\text { Per cent success } \\
\text { 60 days after grafting } \\
\text { (DAG) }\end{array}$ & $\begin{array}{c}\text { Per cent survival } \\
\text { 90 days after grafting } \\
\text { (DAG) }\end{array}$ \\
\hline $\mathrm{T}_{1}(\mathbf{6}$ month) & $93.10(74.82)$ & $80.49(64.87)$ \\
\hline $\mathrm{T}_{2}(\mathbf{5}$ and half month) & $81.89(65.01)$ & $70.68(57.42)$ \\
\hline $\mathrm{T}_{3}(\mathbf{5}$ month) & $87.12(69.05)$ & $79.79(63.65)$ \\
\hline $\mathrm{T}_{4}(\mathbf{4}$ and half month) & $89.46(72.43)$ & $61.34(51.59)$ \\
\hline $\mathrm{T}_{5}(\mathbf{4}$ month) & $86.69(68.91)$ & $58.26(49.76)$ \\
\hline $\mathrm{T}_{6}(\mathbf{3}$ and half month) & $81.04(65.45)$ & $64.43(53.43)$ \\
\hline $\mathrm{T}_{7}(\mathbf{3}$ month) & $81.63(65.36)$ & $72.82(59.25)$ \\
\hline S.Em \pm & 4.116 & 3.903 \\
\hline CD at $\mathbf{5} \%$ & $\mathrm{NS}$ & $\mathrm{NS}$ \\
\hline
\end{tabular}

DAG- Days after grafting NS- Non significant; *Values in parenthesis are arc sign transformation data

Results found that there was no significant difference in height of the grafted plants among the different age of rootstocks. However there were significant difference in girth of the grafted plants, number of sprouts and number of leaves. The present studies also revealed that the average number of sprouts and number of leaves were significantly influenced by number of leaves of grafts as influenced by height and thickness of stocks due to the physiological maturity of rootstock which play an important role in the number of leaves. The average number of sprouts produced on grafts was higher in five and half month old rootstock (3.02) which is on par with three \& six month old rootstock (2.95 and 2.66, respectively) which is significantly superior over other ages of rootstocks (Table 2). Similarly the average number of leaves after 90 days of grafting produced on grafts were higher in five and half month (14.49) followed by three month old rootstocks (13.64). Similar results were obtained by Singh and Srivastava (1980), in softwood grafting recording better results in success as well as extension of growth of shoots at early stage in mango. The lower number of leaves was observed in case of five months old rootstocks compare to three month old rootstocks (Table 2). Better growth of grafts in the present study with young rootstock may be attributed to the higher meristematic activity and juvenility of younger scion, which in turn helped for early sprout initiation. Perhaps early sprouting followed by optimum temperature and humidity might be responsible for production of more number of leaves. This may be due to synthesis of more photosynthates. Patel and Amin (1981) opined that age of rootstocks did not influence vegetative growth of grafts and it may be the environmental condition that influences the growth of grafts.

The results of the investigation showed that different age of the rootstocks recorded higher the graft success and survivability percentage. The growth characters were influenced by different age of rootstocks.

\section{References}

Dambal, R., 1999, Studies on softwood grafting in mist house conditions. M.Sc. Thesis, University of Agricultural Sciences, Dharwad.

Hartmann, H.T., Kester, D.E., Davis, F.T. and Robert, L.G., 1997. The development of seeds. In Plant Propagation: Principles and Practices, Prentice Hall of India 
Private Limited, New Delhi, pp.130144.

Hayes, W.B., 1960, Fruit growing in India. Kitabistan, Allahabad, India, pp. 389394.

Jayaramagowda, B. and Melanta, K.R., 1989, Vegetative propagation of cashew (Anacardium occidentale L.) by grafting. The Cashew. 3(2): 13-14.

Muniswami, K.P., 1979, Cashew grafts under mist conditions. Cashew Causerie, 1(2): 16-20.

Ochse, J.J., Soule, J.J., Dijkman, M.J. and Wehbero, C. 1961. Tropical and Subtropical Agriculture, Macmillan, New York.

Patel, B.M. and Amin, R.S., 1981,
Investigation into the best period of softwood grafting in mango. Punjab Horticultural Journal, 23(1/2): 29-33.

Reddy, C.V. and Melanta, K.R., 1988, Effect of age of rootstock on the success of softwood grafting of mango in containers in situ. South Indian Horticulture, 36(3): 143-145.

Sathishkumar, V., 2001, Studies on wedge grafting in tamarind (Tamarindus indica L.). M.Sc (Agri.) Thesis, University of Agricultural Sciences, Dharwad.

Singh, N.P. and Srivastava, R.P., 1980, A new approach double grafting in mango. Current Science, 49(17): 678-679

\section{How to cite this article:}

Chongtham Allaylay Devi, G.S.K. Swamy, Brij Bihari Pandey, Nagesh Naik, P.M. Sampath, G.J. Suresha and Mukesh L. Chavan. 2018. Studies on Success of Different Age Rootstocks of Softwood Grafting in Jamun (Syzygium cuminii Skeels). Int.J.Curr.Microbiol.App.Sci. 7(02): 3158-3165. doi: https://doi.org/10.20546/ijcmas.2018.702.380 